\title{
Aerosol models for the CALIPSO lidar inversion algorithms
}

\author{
Ali H. Omar ${ }^{1}$, David Winker, Jae-Gwang Won* \\ NASA Langley Research Center, Atmospheric Sciences, MS 401 A, Hampton, VA 23681 \\ *Seoul National University
}

\begin{abstract}
We use measurements and models to develop aerosol models for use in the inversion algorithms for the Cloud Aerosol Lidar and Imager Pathfinder Spaceborne Observations (CALIPSO). Radiance measurements and inversions of the AErosol RObotic NETwork (AERONET ${ }^{1,2}$ ) are used to group global atmospheric aerosols using optical and microphysical parameters. This study uses more than $10^{5}$ records of radiance measurements, aerosol size distributions, and complex refractive indices to generate the optical properties of the aerosol at more 200 sites worldwide. These properties together with the radiance measurements are then classified using classical clustering methods to group the sites according to the type of aerosol with the greatest frequency of occurrence at each site. Six significant clusters are identified: desert dust, biomass burning, urban industrial pollution, rural background, marine, and dirty pollution. Three of these are used in the CALIPSO aerosol models to characterize desert dust, biomass burning, and polluted continental aerosols. The CALIPSO aerosol model also uses the coarse mode of desert dust and the fine mode of biomass burning to build a polluted dust model. For marine aerosol, the CALIPSO aerosol model uses measurements from the SEAS experiment ${ }^{3}$. In addition to categorizing the aerosol types, the cluster analysis provides all the column optical and microphysical properties for each cluster.
\end{abstract}

Keywords: Aerosol types, optical properties, cluster analysis, aerosol measurements and models.

\section{INTRODUCTION}

Global aerosol properties are important not only for use in radiative transfer models but also as inputs to the inversion algorithms of satellite-based measurements of aerosol optical properties. As we approach an era of unprecedented global coverage of aerosol profile measurements (GLAS, CALIPSO) to augment the satellite measurements of aerosol optical depths by passive instruments (MODIS, MISR, POLDER, TOMS, SAGE) there is a need for well characterized aerosol properties. In its most recent report, the Intergovernmental Panel on Climate Change ${ }^{4}$ found that radiative forcing by aerosols is the most uncertain of all radiative forcing estimates. Reducing these uncertainties calls for expanded aerosol measurements and studies to characterize different types of aerosols and sources ${ }^{5}$. Tropospheric aerosols are diverse and their properties depend on sources, emission rates, and removal mechanisms and can be highly variable. To understand and quantify aerosol effects, there have been several domestic and international campaigns to characterize aerosol physical and chemical properties, and process studies. These include the Aerosol Characterization Experiments (ACE -1, -2, -Asia), the Tropospheric Aerosol Radiative Forcing Observational Experiment (TARFOX), the Smoke, Clouds, and Radiation-B (SCAR-B) experiment, and the Indian Ocean Experiment (INDOEX). ACE-1 took place south of Australia in NovemberDecember 1995 and measured properties of the natural aerosol in the remote marine boundary layer ${ }^{6}$. ACE-2 took place in the North Atlantic Ocean in June-July 1997, and focused on the radiative effects and processes controlling anthropogenic aerosols from Europe and desert dust from Africa as they were transported over the North Atlantic Ocean $^{7}$. ACE-Asia took place during the spring of 2001 off the coast of China, Japan and Korea. This region includes many types of aerosol particles of widely varying composition and sizes derived from one of the largest aerosol source regions on Earth. ACE-Asia made several important measurements of wind-blown dust, urban pollution and marine aerosols. TARFOX ${ }^{8}$, designed to measure and analyze aerosol properties and effects along the US eastern seaboard, took place on July 10-31, 1996. INDOEX ${ }^{9}$ measured aerosol properties over the tropical Indian Ocean in 1998 and 1999. The large aerosol optical thicknesses $(\sim 0.5)$ and the prominent role of the carbonaceous aerosols in the extinction budget during most of INDOEX underline the need to develop long-term records of these species.

In many cases, we are likely to use mean properties sorted by location or type to represent aerosol characteristics in both radiative transfer calculations ${ }^{10-13}$ and inversion algorithms of satellite measurements ${ }^{14,15}$. Assigning a set

\footnotetext{
${ }^{1}$ ali.h.omar@nasa.gov
} 
of mean aerosol physical and chemical properties to a given location based on a long-term average has significant shortcomings. This is because at any given location, the aerosol type is highly variable on time scales as short as a few hours ${ }^{16,17}$. These variations result from transport of distinct airmasses to a site and non-systematic events such as fires, wind gusts, hurricanes, tornadoes, and land clearing and development activities. These variations lead to diverse aerosol characteristics at each site on time scales of a few hours and preclude the long term averaging of properties to develop a representative set of characteristics for a site or region. Aerosol optical measurements must therefore be made at short time scales (about 30 minutes) to develop a large data base which can be used to derive statistically significant correlations. The AErosol RObotic NETwork (AERONET ${ }^{1}$ ) measurements are likely to provide a data base with a fine temporal resolution albeit for column rather than vertically-resolved measurements. AERONET is an automatic robotic Sun and sky scanning measurement network that has grown rapidly to over 200 sites worldwide. AERONET uses multi-angle radiance measurements to retrieve the discrete aerosol size distributions in 22 size bins ranging from 0.05 to $15 \mu \mathrm{m}$ and the complex refractive index. The network has the important features of uniform data collection, calibration, and data processing procedures. This study uses the whole AERONET record of measurements and inversions to develop a type-specific set of mean optical properties of aerosols. Cluster analysis is used for categorization of atmospheric aerosol types. Six significant types: desert dust, biomass burning, polluted continental, clean continental, marine aerosol, and dirty pollution are suggested by the cluster analysis. In this classification, clean continental refers to a lightly-loaded soot-free pollution normally found in rural areas and is good approximation for background aerosol. Dirty pollution refers to pollution containing significant amounts of absorbing species.

\section{AERONET DATA SET}

An attempt is made to use all the available data set of AERONET measurements dating back to 1993 for some sites. These measurements are frequently contaminated by clouds and depending on the cloud reflectivities, can have a significant effect on the sun-sky radiance measurements. This study used the AERONET Level 1 size distribution data and applies a two-part cloud screening scheme. The first part checks the symmetry of the almucantar measurements and the second part is a statistical screening procedure. The almucantar measurement is made at several azimuthal angles with the same elevation angle of the direct sun. For the aureole measurement, the degree of angle change is set to be quite small near the direction of sun. In order to ensure that the sky is clear at the time of the measurement, we calculate the relative error between the seven pairs of data measured on either side of the direct sun. The azimuthal angles of these measurements are $2.0^{\circ}, 2.5^{\circ}, 3.0^{\circ}, 3.5^{\circ}, 4.0^{\circ}, 5.0^{\circ}$, and $6.0^{\circ}$. Using this method ensures that the sky is clear near the measurements because the presence of cloud cover would result in disparities between symmetrical pairs of measurements. The statistical screening procedure is based on the cloud screening method for the direct solar measurement of AERONET sun/sky radiometer. In this procedure, records with optical depths $(\tau)$ and Angstrom coefficients (å) that exceed a fixed number of standard deviations $(\sigma)$ on either side of the mean of the distribution are not included in the analyses. The range of acceptable optical depths is $\tau_{\text {mean }}-\sigma$ to $\tau_{\text {mean }}+3 \sigma$. The acceptable Angstrom coefficients are greater than $a_{\text {mean }}-3 \sigma$. These conditions assume that unrealistically large aerosol extinction values are due to cloud contamination or other transient phenomena. A very small Angstrom coefficient is also indicative of cloud contamination. This cloud screening scheme on the average rejects about $60 \%$ of the data.

\section{CLUSTER ANALYSIS}

Cluster analysis is a statistical tool used for grouping large data sets into several categories using predefined variables. In this study, cluster analysis by partitioning ${ }^{18}$ is used to categorize the AERONET data set based on several optical and physical characteristics of the aerosol. The cluster algorithm uses the 26 parameters in Table 1. Note that the optical depths are not used in the cluster analysis because these depend on the amount of aerosol rather than type. The first two columns of the table are properties from the AERONET inversion algorithms. In the third column are optical properties that can be generated from AERONET inversions of size distribution and complex refractive indices using scattering calculations such as Mie modeling ${ }^{19}$, T-Matrix ${ }^{20}$ or Discrete Dipole Analysis ${ }^{21}$ depending on the scattering calculation used in the AERONET inversion algorithm ${ }^{22,}{ }^{23}$. After clustering, the individual sites are inspected to find the frequency of records in the categories. Site belongs to a category $\mathrm{x}$ if more than $30 \%$ of the records at that site are grouped in cluster $\mathrm{x}$. It is therefore possible for a site to belong to more than one category. This means that the site experiences a high frequency of more than one type of aerosol. 
Table 1. Parameters used in the cluster analysis. The numbers in parentheses denote the number of variables for the given property, e.g., there are two geometric mean radii - a fine and coarse radius.

\begin{tabular}{ccc}
\hline Composition & Size distribution & Optical Properties \\
\hline Complex refractive index (8) & Geometric mean radius (2) & Single scattering albedo (4) \\
Geometric standard deviation (2) & Asymmetry factor (4) \\
Mode total volume (2) & $\begin{array}{l}\text { Extinction to backscatter ratio } \\
(4)\end{array}$ \\
\hline
\end{tabular}

The AERONET algorithm for size distribution retrieval provides the volume distribution data of 22 size bins ( $\mathrm{dV} / \mathrm{dlnr}, \mathrm{V}$ is volume, and $\mathrm{r}$ is radius) from $0.05 \mu \mathrm{m}$ to $15 \mu \mathrm{m}$. The best fit for the AERONET size distribution data is a two-mode log-normal size distribution described by equation (1),

$$
\frac{d V}{d \ln r}=\frac{C_{f}}{\sqrt{2 \pi} \ln \sigma_{f}} \exp \left(-\frac{\left[\ln r-\ln \bar{r}_{f}\right]^{2}}{2\left(\ln \sigma_{f}\right)^{2}}\right)+\frac{C_{c}}{\sqrt{2 \pi} \ln \sigma_{c}} \exp \left(-\frac{\left[\ln r-\ln \bar{r}_{c}\right]^{2}}{2\left(\ln \sigma_{c}\right)^{2}}\right)
$$

where the Cs are total mode volume $\left(\mu \mathrm{m}^{3} / \mu \mathrm{m}^{2}\right)$ and the subscripts $\mathrm{f}$ and $\mathrm{c}$ denote fine and coarse modes, respectively. $\sigma$ is the geometric standard deviation and $\bar{r}$ is the geometric mean radius. This partition of the size distribution into fine and coarse modes yields six parameters by which the size distribution can be described.

Considering both anthropogenic and natural sources, atmospheric aerosols occur in at least five distinct classes: marine aerosol, desert-dust, biomass burning aerosol, urban aerosol and rural -background aerosol. This forms the minimum number of aerosol clusters. The actual number of clusters is determined by calculating the clusters using successively larger cluster numbers until the calculation does not yield any new significant clusters. Having defined the number of categories, a random function is used to determine the initial conditions of each variable. These initial coordinates of the variables are located within one standard deviation of the mean assuming a normal distribution of the variables. The data clusters formed in this way group all records that have statistically significant similarities in one category. At each iteration, each record is assigned to the cluster whose center is "closest" (using a Euclidean distance metric) to the record. When all records have been assigned to individual clusters, new cluster centers are determined by averaging the variables in each cluster. The process is repeated with the new cluster centers until the relative error between the centers of new and old clusters is less than a prescribed value. The distance (normalized by the standard deviation to eliminate bias resulting from the different magnitudes of the variables) between a record and the center of category $\mathrm{j}$ is calculated using equation 2 ,

$$
\text { normalized distance }(\mathrm{j})=\sum_{\substack{\mathrm{j}=26 \\ \mathrm{i}=1 \\ \mathrm{j}=1}}^{\substack{\mathrm{j} \\\{}} \frac{\text { data } \operatorname{record}(\mathrm{i})-\operatorname{center}(\mathrm{j}, \mathrm{i})}{\{\operatorname{standard} \operatorname{deviation}(\mathrm{i})\}^{2}}
$$

The six distances are compared and each record is grouped in the category with the shortest distance to the cluster center. After grouping the records into the six groups, a new center for each cluster is determined by averaging the variables in each cluster. The process is repeated with the new cluster centers until the relative error between the centers of new and old clusters is less than $0.1 \%$. Convergence is achieved within 25 iterations for the various initial conditions. Figure 1 shows a flowchart of the clustering algorithm. 


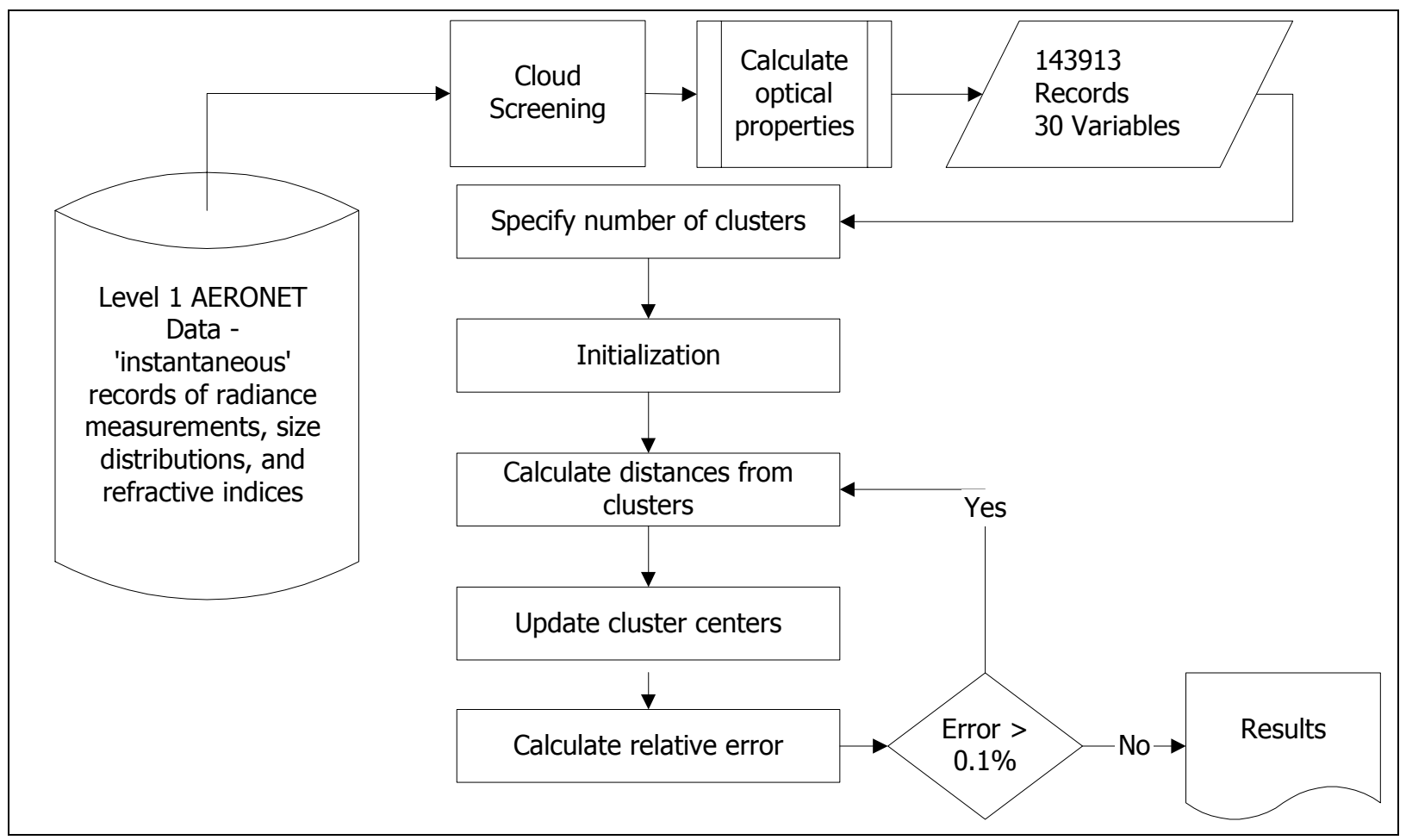

Figure 1. Flowchart of the clustering algorithm used to group 143,913 AERONET records into clusters of with similar composition, size distribution, and optical properties. The convergence is achieved when the cluster centers in 26-parameter space do not change by more than $0.1 \%$ in successive iterations.

\section{THE CATEGORIES OF AEROSOL}

The AERONET data set yielded six distinct clusters described by the column optical and physical properties. After the algorithm has generated the number of aerosol categories, each category is assigned an aerosol type. Aerosol typing of the categories relies on telltale properties such as the fine and coarse fractions, particle size, optical depth, geographic location and in some cases seasonal variation. The effects of non-sphericity on the cluster analysis are unknown but not negligible. Table 2 shows the properties of the six clusters. The values shown in the table are some of coordinates in 26-parameter space of the centers (medoids) of the clusters. The properties of the medoids along with the geographic locations of the sites suggest that categories 1 to 6 are desert dust, biomass burning, rural (background), industrial pollution, marine, and dirty pollution, respectively.

The size distributions and the location of sites belonging to category 1 are Banizoumbou, Ouagadougou, Cape Verde, Ilorin, Solar Village, Bahrain, Kanpur, Dahkla, Sede Boker, Nes Ziona, Maricopa, Ascension Island, La Paguera, and Yulin shown in Fig. 2. All these sites are in desert regions or close to deserts or in regions where desert dust as a result of long-range transport has been observed ${ }^{24-27}$. The mean radius and geometric standard deviation for the fine (coarse) mode is $0.12 \mu \mathrm{m}$ and $1.5(2.8 \mu \mathrm{m}$ and 1.91), respectively. The fine/coarse aerosol ratio by volume is 0.22 , i.e., coarse sizes are dominant as shown in Fig 3a. The medoid properties of these aerosols are consistent with other measurements dust aerosols. The global aerosol model of d'Almeida et al. ${ }^{28}$ estimate dry accumulation and coarse mode radii for dust of $0.27 \mu \mathrm{m}$ and $4.00 \mu \mathrm{m}$, respectively. Tanre et al. ${ }^{24}$ used spectral measurements from both Landsat TM and AERONET to find size distributions for dust aerosols of $0.5 \mu \mathrm{m}$ for the fine mode and 1- $5 \mu \mathrm{m}$ for the coarse mode. Real refractive indices from the same study ranged from $1.46-1.52$. 
Table 2. Summary of the cluster analysis results for 143913 records. The values are the center of each cluster (medoid) and the membership coefficient is an indication of the 'tightness' of each cluster.

\begin{tabular}{lllllll}
\hline & Cat 1 & Cat 2 & Cat 3 & Cat 4 & Cat 5 & Cat 6 \\
\hline Number of Records & 22202 & 26662 & 20307 & 55667 & 6527 & 12548 \\
Single Scat. Albedo $(673 \mathrm{~nm})$ & 0.93 & 0.80 & 0.88 & 0.92 & 0.93 & 0.72 \\
Real Refractive Index $(673 \mathrm{~nm})$ & 1.4520 & 1.5202 & 1.4494 & 1.4098 & 1.3943 & 1.4104 \\
Imaginary Refractive Index $(673 \mathrm{~nm})$ & 0.0036 & 0.0245 & 0.0092 & 0.0063 & 0.0044 & 0.0337 \\
Optical Depth $(673 \mathrm{~nm})$ & 0.327 & 0.190 & 0.036 & 0.191 & 0.140 & 0.100 \\
Angstrom Coefficient $(441 / 673)$ & 0.608 & 1.391 & 1.534 & 1.597 & 0.755 & 1.402 \\
Angstrom Coefficient $(673 / 873)$ & 0.486 & 1.332 & 1.381 & 1.536 & 0.678 & 1.232 \\
Angstrom Coefficient $(873 / 1022)$ & 0.277 & 1.043 & 0.950 & 1.290 & 0.531 & 0.846 \\
Asymmetry factor $(673 \mathrm{~nm})$ & 0.668 & 0.603 & 0.580 & 0.612 & 0.711 & 0.594 \\
Fine mean radius $(\mu \mathrm{m})$ & 0.117 & 0.144 & 0.133 & 0.158 & 0.165 & 0.140 \\
Geo. Standard Dev. $\left(\right.$ fine $\left.^{2}\right)$ & 1.482 & 1.562 & 1.502 & 1.526 & 1.611 & 1.540 \\
Fine total volume $\left(\mu \mathrm{m}^{3} / \mu \mathrm{m}^{2}\right)$ & 0.077 & 0.040 & 0.013 & 0.061 & 0.029 & 0.032 \\
Coarse mean radius $(\mu \mathrm{m})$ & 2.834 & 3.733 & 3.590 & 3.547 & 3.268 & 3.556 \\
Geo. Standard Dev. $(\mathrm{coarse})$ & 1.908 & 2.144 & 2.104 & 2.065 & 1.995 & 2.134 \\
Coarse total volume $\left(\mu \mathrm{m}^{3} / \mu \mathrm{m}^{2}\right)$ & 0.268 & 0.081 & 0.020 & 0.054 & 0.083 & 0.034 \\
Fine fraction by volume & 0.22 & 0.33 & 0.38 & 0.53 & 0.26 & 0.49 \\
Membership Coefficient & 0.92 & 0.93 & 0.94 & 0.93 & 0.91 & 0.89 \\
\hline
\end{tabular}

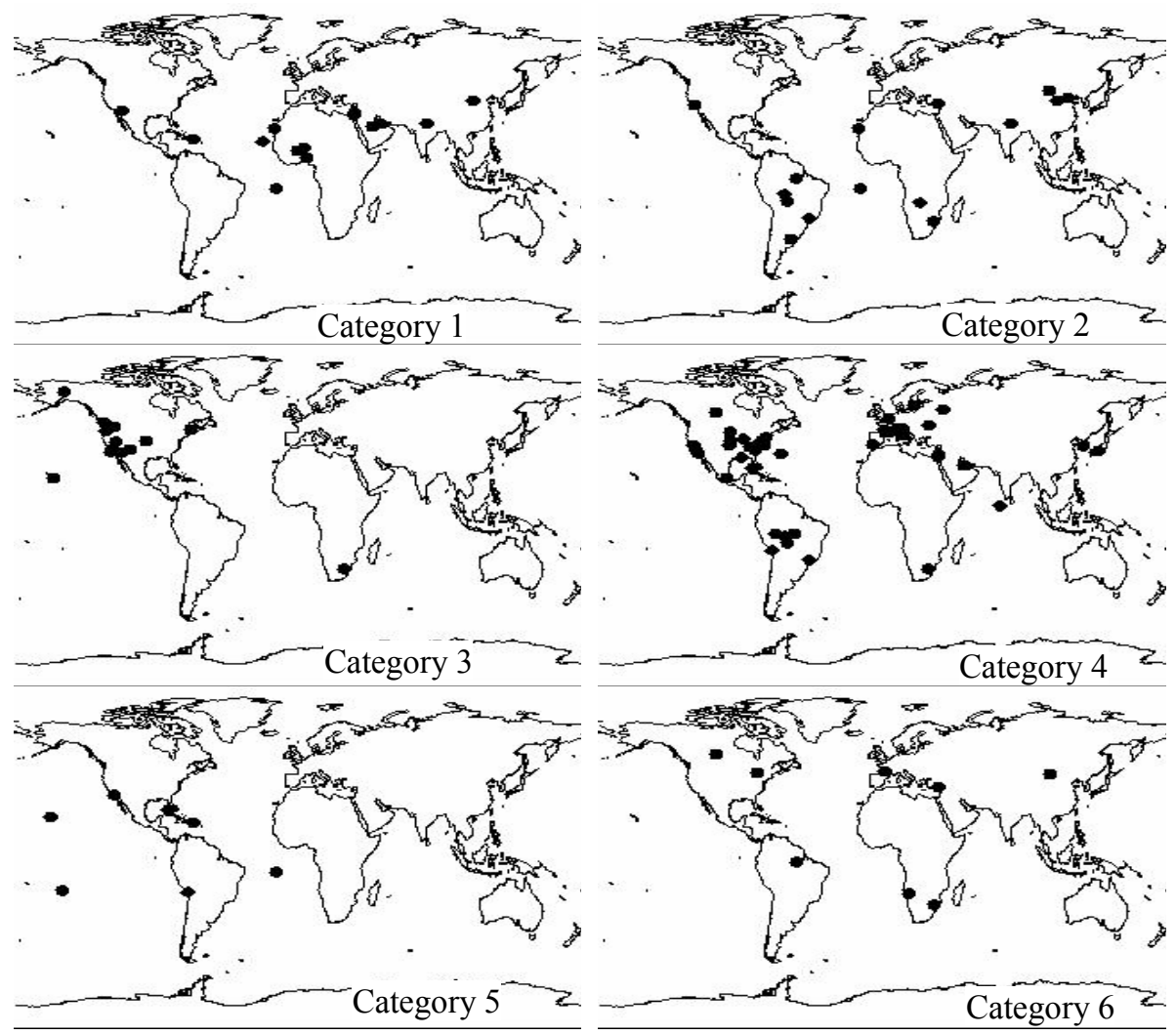

Figure 2. The locations of the six categories. The locations and properties of the categories 1,2, 4,5 and 6 are consistent with desert dust, biomass burning, continental pollution, marine and dirty pollution, respectively. 

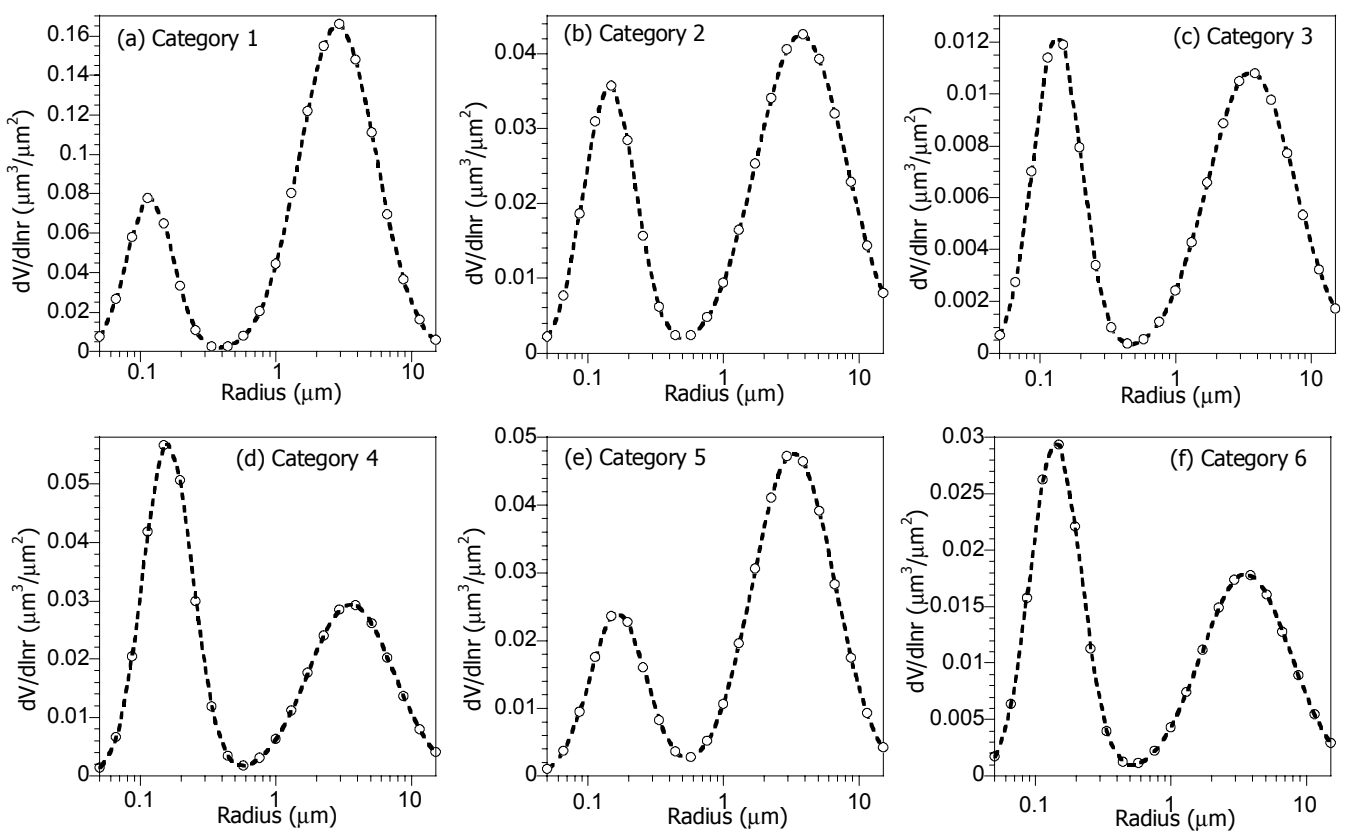

Figure 3. Size distributions of the cluster medoids of the six aerosol categories

Using airborne particle counters, a ground based lidar and sunphotometer, Di Iorio et al. ${ }^{26}$ estimated complex refractive indices of (1.52 to 1.58$)-(0.005$ to 0.007$)$ i for dust aerosols. In the same study they estimate single scattering albedos ranging from $0.71-0.75$. Category 1 aerosols have a mean single scattering albedo of 0.93 which is closer to the values reported by others ${ }^{24}$

Category 2 sites include Skukuza, IMS Metu Erdeml, Egbert, Abracos Hill, Mongu, Cuiaba, Los Fieros, Yulin, CEILAP-BA. The size distributions are described by fine (coarse) radius and standard deviation of $0.15 \mu \mathrm{m}$, and $1.62(3.8 \mu \mathrm{m}$, and 2.1$)$, respectively. The fine-to-coarse aerosol ratio based on the volume distribution is 1.0. Real and imaginary parts $\left(\mathrm{m}_{\mathrm{r}}\right.$ and $\left.\mathrm{m}_{\mathrm{i}}\right)$ of the refractive idex of 1.46 and 0.03 are consistent with measurements of Dubovik et al. ${ }^{13}$ and Ansmann et al. ${ }^{15}$. Using spectrally resolved particle backscatter and extinction measurements, the effective particle radius of free tropospheric aerosol advected from the Indian subcontinent and primarily composed of biomass burning pollution is estimated at $0.17 \mu \mathrm{m}{ }^{29}$. Muller et al.$^{30}$ found effective radii ranging between 0.14 and $0.22 \mu \mathrm{m}$, complex refractive indices of $1.65-(0.03$ to 0.08$) \mathrm{i}$ and single scattering albedos of 0.79 to 0.86 at $532 \mathrm{~nm}$ for the same aerosol plumes. A series of measurements of both microphysical and optical properties of biomass burning aerosols made during the SCAR-B campaign ${ }^{31}$ found values of size distributions, single scattering albedos, complex refractive indices, and optical depths not inconsistent with the values reported for category 2 in Table 2 above.

The Category 3 aerosol is characterized by a low optical depth (0.04) and a relative large frequency of incidence in areas where the atmosphere is expected to be relatively clean, i.e., clean continental or rural background. The members of this category include Mauna Loa, Rairoad Valley, Saturn Island, Sevilleta, Rogers Dry Lake, Bonanza Creek, Rimrock, Maricopa, H. J. Andrews, Howland, Konza EDC, Bethlehem, San Nicolas shown in Figure 2. The fine/coarse mode ratio by volume is 0.4 and a fine (coarse) radius and standard deviation of $0.13 \mu \mathrm{m}$, and 1.50 (3.6 $\mu \mathrm{m}$, and 2.1), respectively. Most of these sites are continental with the exception of Mauna Loa. Though this category has a large number of records (20307), the low optical depth of the measurements means necessarily that the retrieval accuracy is significantly deteriorated. For all AERONET measurements the accuracy of the single scattering albedo, and refractive indices significantly decreases for $441 \mathrm{~nm}$ optical depths of less than $0.2^{25,32}$.

Category 4 aerosols are most prevalent at Walker Branch, Venice, ISDGM CNR, Moscow MSU MO, MD Science Center, Columbia SC, GSFC, Wallops, SERC, Avignon, UCLA, Cart Site, Mexico City, Toulouse, Anmyon, Lille, Moldova, Stennis, Rome Tor Vergat, Konza EDC, Rio Branco, Nes Ziona, Ispra, Shirahama, La Jolla, Bondville, COVE, Dry Tortugas, Alta Floresta, Arica, Fresno, GISS, Sao Paulo, Gotland, Bethlehem, Abracos Hill, Bahrain, Sioux Falls, Los Fieros, Corcoran, Sede Boker, Kaashidhoo, El Arenosillo, Bermuda, Bordeaux, Mongu, 
Waskesiu. The fine fraction by volume is 0.53 and the size distribution is described by a fine (coarse) radius and standard deviation of $0.16 \mu \mathrm{m}$, and $1.53(3.5 \mu \mathrm{m}$, and 2.1), respectively. The location of the aerosols (near or in urban centers), and the composition (mean refractive index of $1.41-0.006 \mathrm{i}$ ) are consistent with urban pollution. Category 5 sites are Lanai, Tahiti, Arica, La Paguera, Dry Tortugas, Ascension Islan, La Jolla. The fine-to-coarse volume ratio is 0.26 and the refractive index is $1.39-0.004 \mathrm{i}$ at $673 \mathrm{~nm}$. The global aerosol models of d'Ameida et al. ${ }^{28}$ estimate an oceanic aerosol refractive index of 1.38 with a negligibly small imaginary part. All the sites are islands or coastal sites. The size distribution is described by a fine (coarse) radius and geometric standard deviation of $0.17 \mu \mathrm{m}$, and $1.6(3.3 \mu \mathrm{m}$, and 2.0), respectively. The coarse mode is most likely seasalt. The fine mode, whose contribution is most likely responsible for the enhancement of the imaginary part of the total refractive index, is most likely smoke or biomass burning aerosol. It is therefore likely that Category 5 is marine aerosol mixed with biomass burning smoke or industrial pollution.

Category 6 sites are Egbert, Skukuza, Bordeaux, Etosha Pan, Belterra, IMS Metu Erdeml, Waskesiu, Dalanzadgad. Three of these sites (Skukuza, IMS Metu Erdeml, Dalanzadgad) are also found in category 2. This class of aerosols (referred to as dirty pollution) is characterized by a size distribution similar to category 4 (industrial pollution) with a larger imaginary index of refraction (0.034) and small single scattering albedos. These are most likely aerosols with a large fraction of elemental carbon.

Only categories 1,2, and 4 are used for the CALIPSO models. Categories 3 has low mean optical depths and therefore the retrievals are highly uncertain, and category 5 has a small number of records.

\section{SUMMARY OF THE AERONET CLUSTER STUDIES}

The AERONET classification yields five groups of aerosols shown in Table 3. The table also shows the main constituent species of each type. Desert dust is mostly mineral soil. Biomass burning is an aged smoke aerosol consisting primarily of soot and organic carbon (OC). Background aerosol is a lightly loaded aerosol consisting of sulfates $\left(\mathrm{SO}_{4}{ }^{2-}\right)$, nitrates $\left(\mathrm{NO}_{3}{ }^{-}\right), \mathrm{OC}$, and Ammonium $\left(\mathrm{NH}_{4}^{+}\right)$. Marine aerosol consists primarily of seasalt $(\mathrm{NaCl})$. Both polluted continental and dirty pollution consist of the same species but the large imaginary part of the refractive index of dirty pollution suggests that this type of aerosol contains a significantly larger (than polluted continental) fraction of soot.

Table 3. Aerosol types determined by the cluster analysis of AERONET data

\begin{tabular}{ll}
\hline Cluster Category & Aerosol Type \\
\hline 1 & Desert dust (Mineral dust) \\
2 & Biomass burning (soot $+\mathrm{OC})$ \\
3 & Background/rural $\left(\mathrm{SO}_{4}{ }^{2-}, \mathrm{NO}_{3}^{-}, \mathrm{OC}, \mathrm{NH}_{4}^{+}\right)$ \\
4 & Polluted continental $\left(\mathrm{SO}_{4}{ }^{2-}, \mathrm{NO}_{3}^{-}, \mathrm{OC}, \mathrm{NH}_{4}{ }^{+}+\right.$soot $)$ \\
5 & Marine(NaCl) \\
6 & Dirty pollution $\left(\mathrm{SO}_{4}{ }^{2-}, \mathrm{NO}_{3}^{-}, \mathrm{OC}, \mathrm{NH}_{4}^{+}+\right.$soot $)$ \\
\hline
\end{tabular}

\section{CONSISTENCY OF AEROSOL MICROPHYSICAL PROPERTIES}

To check for the consistency of the individual categories, we divided the measurements in each category into five optical depth classes and plotted the size distributions of each class within a category. The results are shown in Figure 4. Note that for each category, the magnitude of the fine and coarse mode amplitudes of the size distribution denote fine and coarse loading, respectively. As shown, the mode amplitudes increase with the optical depth for all types. The optical depth is an extensive property as is the mode amplitude and this behavior is expected for a given aerosol type. The fine and coarse mean radii and geometric standard deviations, on the other hand, are intensive properties, i.e., properties that depend on the type of aerosol and not the the amount or loading. These are relatively constant across optical depth classes within categories. This means that despite changes in the optical depth, the aerosol type is consistently the same in each category. While this is not a sufficient validation of the clustering method, it is an indication of the ability of the algorithm to group similar data sets using the 
prescribed variables. Since some of these records span a period of nearly a decade, the most conclusive validation of the clustering algorithm would be to examine a climatology of in situ measurements at the individual sites. While such in situ data may become available for some sites in future, there is currently no climatology of aerosol types at any of the AERONET sites. Even if such a climatology were available, it would only be useful in locations were a given type of aerosol (say polluted continental) was dominant almost to the exclusion of all other types. For sites that experience several different types of aerosols, climatologies based on time averages longer than a few hours would be misleading.
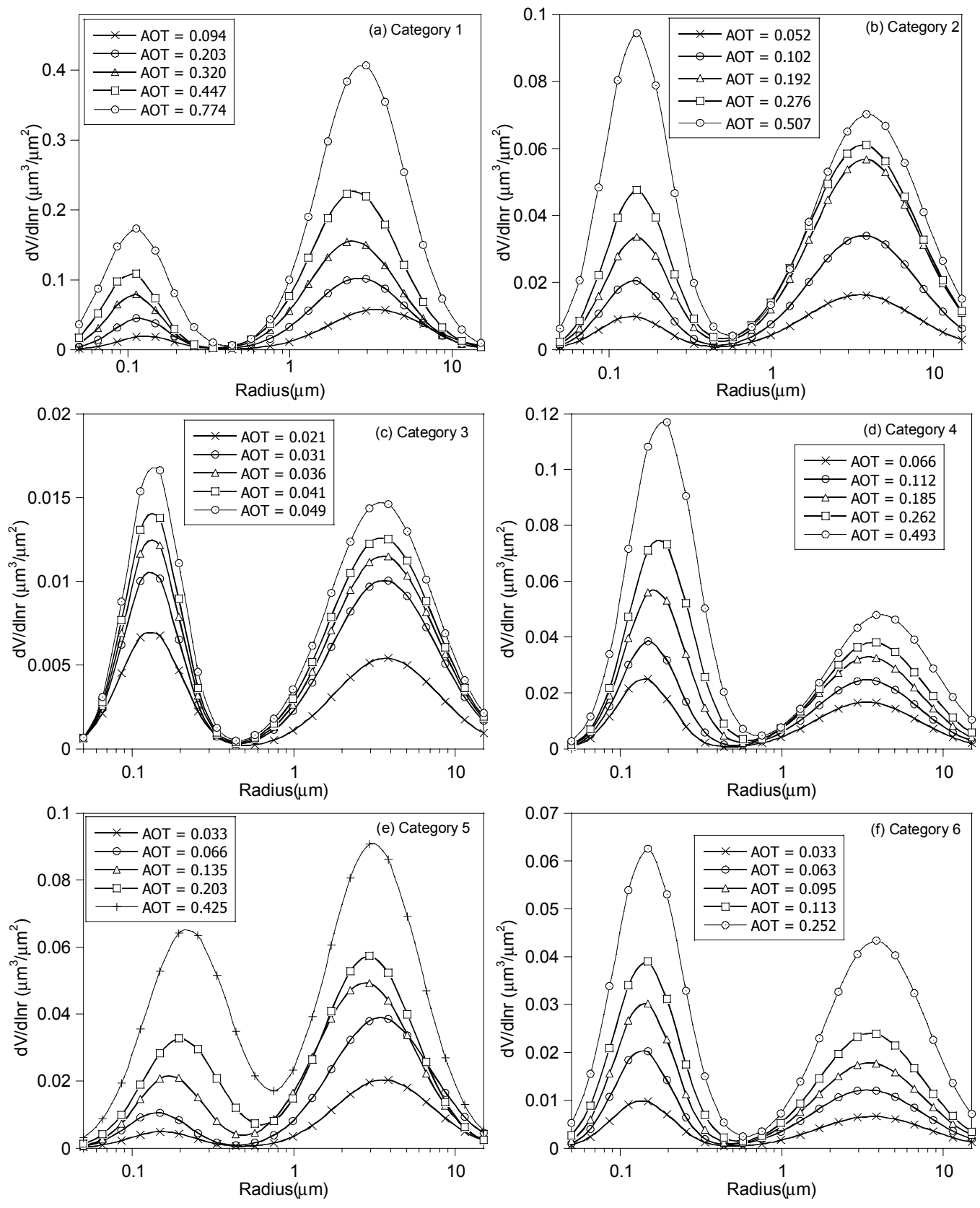

Figure 4. Size distributions of dust (a), biomass burning (b), background/rural (c), polluted continental (d), marine (e), and dirty pollution (f) aerosol, i.e., categories $1,2,3,4,5$, and 6 respectively. The data in each category was partitioned into five aerosol optical thickness (AOT) classes. 


\section{CALIPSO AEROSOL MODELS}

Fig. 5 (a)-(f) show the physical and chemical properties of the CALIPSO aerosol models and the corresponding extinction/backscatter values at $532 \mathrm{~nm}$ and $1064 \mathrm{~nm}$. The AERONET cluster analysis yielded six distinct types of aerosol. Only three of these clusters (desert dust, biomass burning, polluted continental, Fig. 6a, b, and d, respectively) were used to characterize the CALIPSO aerosol models.
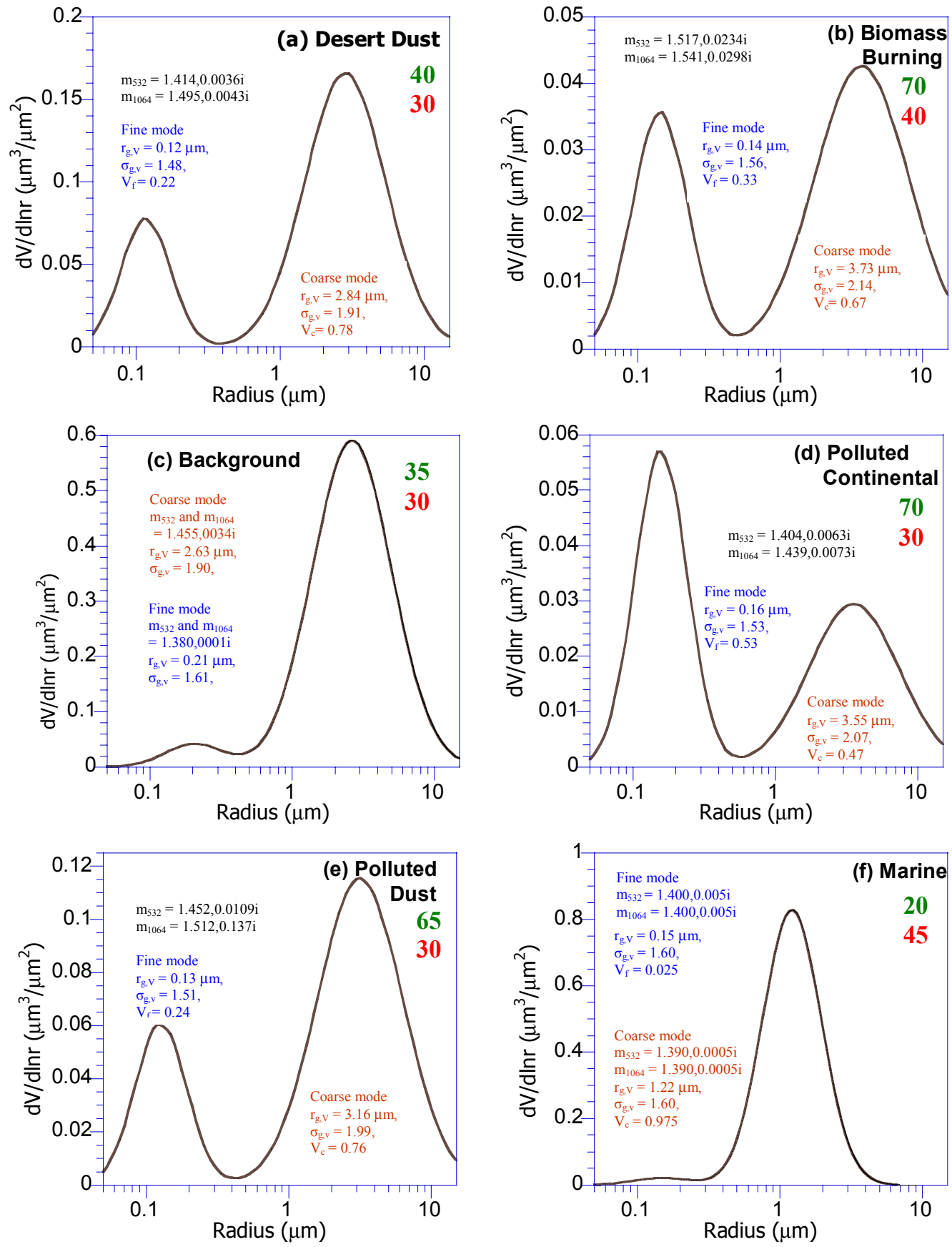

Figure 5. The size distributions and microphysical properties of the CALIPSO aerosol models. For each model the extinction/backscatter ratio $S_{a}$ (in sr) at $532 \mathrm{~nm}$ (top) and $1064 \mathrm{~nm}$ (bottom), is shown in the left hand quadrant. $\mathrm{r}_{\mathrm{g}, \mathrm{v}}$ and $\sigma_{\mathrm{g}, \mathrm{v}}$ are the geometric mean radii and standard deviations of the distribution respectively. $\mathrm{m}_{\mathrm{i}}$ is the complex refractive index at wavelength $\mathrm{i}$ in $\mathrm{nm} . \mathrm{C}_{\mathrm{f}}$ and $\mathrm{C}_{\mathrm{v}}$ are the fine and coarse volume fractions of the distribution. 
The CALIPSO model of background and marine aerosols are not derived from the AERONET measurements. The AERONET records of the background cluster had low mean optical depths ( $<0.05$ at $673 \mathrm{~nm})$. The microphysical properties derived from these are likely to have large uncertainties ${ }^{25}$. The CALIPSO background aerosol model (Fig. 5c) was derived by fitting size distributions and refractive indices to measurements of extinction/backscatter ratios of long-range continental transport ${ }^{33}$. The AERONET marine aerosol cluster is comprised of a small number of records $(<4 \%$ of the total). The CALIPSO marine aerosol model (Fig. $5 \mathrm{f})$ is derived from the parameters measured during the SEAS experiment ${ }^{3}$. The CALIPSO polluted dust is a mixture of the AERONET desert dust (coarse mode) and biomass burning (fine mode) clusters (Fig 5e).

\section{CONCLUSION}

We have used measurements and models to develop aerosol models for use in the CALIPSO lidar inversion algorithms. The CALIPSO aerosol model consist of six aerosol types: Desert dust, biomass burning, background, polluted continental, polluted dust, and marine. A global data set, AERONET, has been used to identify main clusters of aerosol types and to determine microphysical properties of aerosol groups. This characterization is augmented by measurements where the uncertainty in the AERONET retrievals is expected to be high. The effects of non-sphericity on the cluster analysis are unknown but not negligible. These need to be addressed in future studies. The CALIPSO models will evolve with new measurements and, upon launch the CALIPSO data will significantly enhance the available data base of the characteristics of aerosol types. Such data sets will be used to further refine the probability distribution functions and threshold values for use in the algorithms.

\section{REFERENCES}

1. Holben, B. N., T.F.Eck, I.Slutsker, D.Tanre, J.P.Buis, A.Setzer, E.Vermote, J.A.Reagan, Y.Kaufman, T.Nakajima, F.Lavenu, I.Jankowiak \& A.Smirnov, "AERONET - A federated instrument network and data archive for aerosol characterization", Rem. Sens. Env.. 66, 1998.

2. Holben, B. N., D. Tanre, A. Smirnov, T. F. Eck, I. Slutsker, N. Abuhassan, W. W. Newcomb, J. Schafer, B. Chatenet, F. Lavenue, Y. J. Kaufman, J. V. Castle, A. Setzer, B. Markham, D. Clark, R. Frouin, R. Halthore, A. Karnieli, N. T. O'Neill, C. Pietras, R. T. Pinker, K. Voss \& G. Zibordi, "An emerging ground-based aerosol climatology: Aerosol Optical Depth from AERONET", J. Geophys. Res.. 106, 12067-12097, 2001.

3. Masonis, S. J., T. L. Anderson, D. S. Covert, V. Kapustin, A. D. Clarke, S. Howell \& K. Moore, "A study of the extinction-to-backscatter ratio of marine aerosol during the Shoreline Environmental Aerosol Study (SEAS)", Journal of Atmospheric and Oceanic Technology. Submitted, 2002.

4. IPCC, Climate Change 2001: The Scientific Basis: Contribution of Working Group I to the Third Assessment Report of the Intergovernmental Panel on Climate Change (IPCC), Cambridge University Press. Cambridge, UK, 2001.

5. NRC. 1996. A Plan for a Research Program on Aerosol Radiative Forcing and Climate Change.

6. Bates, T. S., B. J. Heuebert, J. L. Gras, F. B. Griffiths \& P. A. Durkee, "International Global Atmospheric Chemistry (IGAC) Project's First Aerosol Characterization Experiment (ACE 1): Overview", Journal of Geophysical Research. 103, 16297-16318, 1998.

7. Raes, F., T. Bates, F. McGovern \& M. V. Liedekerke, "The 2nd Aerosol Characterization Experiment (ACE2): general overview and main results", Tellus. 52B, 111-125, 1999.

8. Russell, P. B., P. V. Hobbs \& L. L. Stowe, "Aerosol Properties and Radiative Effects in the United States East Coast Haze Plume: An Overview of the Tropospheric Aerosol Radiative Forcing Observational Experiment (TARFOX)", Journal of Geophysical Research. 104, 2213-2222, 1999. 
9. Ramanathan, V., P. J. Crutzen, J. Lelieveld, A. P. Mitra, D. Althausen, J. Anderson, M. O. Andreae, W. Cantrell, G. R. Cass, C. E. Chung, A. D. Clarke, J. A. Coakley, W. D. Collins, W. C. Conant, F. Dulac, J. Heintzenberg, A. J. Heymsfield, B. Holben, S. Howell, J. Hudson, A. Jayaraman, J. T. Kiehl, T. N. Krishnamurti, D. Lubin, G. MacFarquhar, T. Novakov, J. A. Ogren, I. A. Podgorny, K. Prather, K. Priestley, J. M. Prospero, P. K. Quinn, K. Rajeev, P. Rasch, S. Rupert, R. Sadourny, S. K. Satheesh, G. E. Shaw, P. Sheridan \& F. P. J. Valero, "The Indian Ocean Experiment: An Integrated Analysis of the Climate Forcing and Effects of the Great IndoAsian Haze." J. Geophys. Res.. 106, 28371-28398, 2001.

10. Kiehl, J. T. \& B. P. Briegleb, "The relative roles of sulfate aerosols and greenhouse gases in climate forcing", Science. 260, 311-314, 1993.

11. Kiehl, J. T. \& H. Rodhe. 1995. Modeling geographical and seasonal forcing due to aerosols. Dahlem Workshop on Aerosol Forcing of Climate.

12. Nemesure, S., R. Wagener \& S. E. Schwartz, "Direct shortwave forcing of climate by anthropogenic sulfate: Sensitivity to particle size, composition, and relative humidity", Journal of Geophysical Research. 100, 2610526116, 1995.

13. Penner, J. E., R. E. Dickinson \& C. A. O'Neill, "Effects of Aerosol from Biomass Burning on the Global Radiation Budget", Science. 256, 1432-1434, 1992.

14. Tanre, D., L. A. Remer, Y. J. Kaufman, S. Mattoo, P. V. Hobbs, J. M. Livingstone, P. B. Russell \& A. Smirnov, "Retrieval of aerosol optical thickness and size distribution over ocean from the MODIS airborne simulator during TARFOX", Journal of Geophysical Research. 104, 2261-2278, 1999.

15. Kahn, R., P. Banerjee \& D. McDonald, "Sensitivity of multiangle imaging to natural mixtures of aerosols over ocean", Journal of Geophysical Research. 106, 18219-18238, 2001.

16. Sheridan, P. J., D. J. Delene \& J. A. Ogren, "Four years of continuous surface aerosol measurements from the Department of Energy's Atmospheric Radiation Measurement Program Southern Great Plains Cloud and Radiation Testbed site", Journal of Geophysical Research. 106, 20735-20747, 2001.

17. Anderson, T. L., A. R. J. Charlson, D. M. Winker, J. A. Ogren \& K. Holmen, "Mesoscale Variations Of Tropospheric Aerosols", J. Atmos. Sci.. 60, 119-136, 2003.

18. Kaufman, L. \& P. J. Rousseeuw, Finding Groups in Data, John Wiley and Sons. New York, 1990.

19. Mie, G., "Beigrade zur optik trüber medien, speziell kolloidaler metallösungen", Ann. Physik. 25, 337-445, 1908.

20. Mischenko, M. I., A. A. Lacis, B. E. Carlson \& L. D. Travis, "Nonsphericity of dust-like tropospheric aerosols: implications for aerosol remote sensing and climate modeling", Geophysical Research Letters. 22, 1077 $1080,1995$.

21. Draine, B. T. \& P. J. Flatau, " Discrete dipole approximation for scattering calculations", J. Opt. Soc. Am.. A11, 1994.

22. Dubovik, O. \& M. D. King, "A flexible inversion algorithm for retrieval of aerosol optical properties from Sun and sky radiance measurements", J. Geophys. Res.. 105, 9791-9806, 2000.

23. Dubovik, O., B. N. Holben, T. Lapyonok, A. Sinyuk, M. I. Mischenko, P. Yang \& I. Slutsker, "Non-spherical aerosol retrieval method employing light scattering by spheroids", Geophys. Res. Lett.. 29, 2002. 
24. Tanre, D., Y. J. Kaufmann, B. N. Holben, B. Chatenet, A. Karnieli, F. Lavenu, L. Blarel, L. A. Remer \& A. Smirnov, "Climatology of dust aerosol size distribution and optical properties derived from remotely sensed data in the solar spectrum", J. Geophys. Res.. 106, 18205-18217, 2001.

25. Dubovik, O., B. N. Holben, T. F. Eck, A. Smirnov, Y. J. Kaufman, M. D. King, D. Tanre \& I. Slutsker, "Variability of absorption and optical properties of key aerosol types observed in worldwide locations", Journal of Atmospheric Sciences. 59, 590-608, 2002.

26. Di Iorio, T., A. di Sarra, W. Junkermann, M. Cacciani, G. Fiocco \& D. Fua, "Tropospheric aerosols in the Mediterranean: 1. Microphysical and optical properties", J. Geophys. Res.. 108, 2003.

27. Colarco, P., O. B. Toon \& B. Holben, "Saharan dust transport to the Caribbean during PRIDE: 1. Influence of dust sources and removal mechanisms on the timing and magnitude of downwind aerosol optical depth events from simulations of in situ and remote sensing observations", J. Geophys. Res.,. 108, 8589, 2003.

28. d'Almeida, G. A., P. Koepke \& E. P. Shettle, Atmospheric Aerosols: Global Climatology and Radiative Characteristics, A. Deepak Publishing. Hampton, VA, 1991.

29. Ansmann, A., D. Althausen, U. Wandinger, K. Franke, D. Muller, F. Wagner \& J. Heintzenberg, "Vertical profiling of the Indian aerosol plume with six-wavelength lidar during INDOEX: A first case study", Geophys. Res. Lett.. 27, 963-966, 2000.

30. Müller, D., F. Wagner, D. Althausen, U. Wandinger \& A. Ansmann, "Physical properties of the Indian aerosol plume derived from six-wavelength lidar observations on 25 March 1999 of the Indian Ocean Experiment", Geophysical Research Letters. 27, 1403-1406, 2000.

31. Kaufman, Y. J., P. V. Hobbs, V. W. J. H. Kirchhoff, P. Artaxo, L. A. Remer, B. N. Holben, M. D. King, D. E. Ward, E. M. Prins, K. M. Longo, L. F. Mattos, C. A. Nobre, J. D. Spinhirne, Q. Ji, A. M. Thompson, J. F. Gleason, S. A. Christopher \& S.-C. Tsay, "Smoke, Clouds, and Radiation-Brazil (SCAR-B) experiment", J. Geophys. Res.. 103, 31783-31808, 1998.

32. Dubovik, O., A. Smirnov, B. N. Holben, M. D. King, Y. J. Kaufman, T. F. Eck \& I. Slutsker, "Accuracy assessment of aerosol optical properties retrieval from AERONET sun and sky radiance measurements", $J$. Geophys. Res.. 105, 9791-9806, 2000.

33. Anderson, T. L., S. J. Masonis, D. S. Covert \& R. J. Charlson, "In situ measurements of the aerosol extinction-to-backscatter ratio at a polluted continental site", Journal of Geophysical Research. 105, 26907$26915,2000$. 